\title{
PENGEMBANGAN MEDIA PEMBELAJARAN MEMBACA BERBANTUAN KOMPUTER UNTUK PESERTA DIDIK KELAS 1 SEKOLAH DASAR
}

\author{
Ary Isdianto, Pujiati Suyata \\ Balai Pengembangan Media Radio Pendidikan, Universitas Negeri Yogyakarta \\ aisto_bpmr@yahoo.com
}

\begin{abstract}
Abstrak
Penelitian ini bertujuan untuk mengembangkan secara sistematis media pembelajaran membaca berbantuan komputer untuk peserta didik kelas satu sekolah dasar yang layak dan menarik berdasarkan validasi pakar dan uji pengguna. Penelitian ini merupakan jenis penelitian pengembangan. Produk yang berupa media pembelajaran dikembangkan melalui beberapa langkah, yaitu: (1) analisis kebutuhan berupa pengumpulan informasi awal, (2) proses pengembangan, dan (3) uji lapangan. Instrument yang digunakan dalam penelitian ini meliputi lembar evaluasi ahli dan pengguna. Hasil akhir penelitian pengembangan ini adalah software media pembelajaran membaca berbantuan komputer untuk peserta didik kelas 1 sekolah dasar yang siap digunakan baik dalam proses belajar mengajar di kelas ataupun digunakan secara mandiri. Penilaian ahli materi mengenai kualitas media PBK yang dikembangkan ini adalah sangat baik, ahli media dan guru, dan peserta juga menilai sangat baik, dan peserta didik pada uji coba lapangan memberikan tanggapan sangat baik. Adapun hasil pretes dan postes menunjukkan bahwa media ini efektif untuk meningkatkan kemampuan baca peserta didik.
\end{abstract}

Kata Kunci: media, pembelajaran, membaca

\section{DEVELOPING COMPUTER ASSISTED LEARNING MEDIA IN TEACHING READING FOR THE FIRST GRADE OF ELEMENTARY SCHOOL STUDENTS}

\author{
Ary Isdianto, Pujiati Suyata \\ Balai Pengembangan Media Radio Pendidikan, Universitas Negeri Yogyakarta \\ aisto_bpmr@yahoo.com
}

\section{Abstract}

This study aims at developing computer assisted learning media for the first grade of elementary school students. This learning media is intended to help the students learning reading. It is developed systematically based on the expert and user validations in such a way so that this media can be interesting and appropriate for the users. This study is categorized as research and development. Here, the writer has tried to develop a learning media product. This product has been evaluated so that it can be used to help the first grade of elementary school students in solving the learning problem. There are some steps in developing this research: (1) need analysis, the process of identifying and evaluating needs; (2) development process; and (3) evaluation process. The instruments used are the evaluation worksheets for experts and users. The result of this development research is a software program, known as computer assisted learning which can be used as a media for teaching reading especially for the first grade of elementary school students. This media can be used classically by the teachers or be used independently by the students. According to the material expert, the quality of the developed media is very good, and according to the media expert, teachers, and the students, the quality of the media developed is also very good. The result of the pretest and post test shows that the media is effective to improve the reads ability.

Keywords: media, instructional, reading 


\section{Pendahuluan}

Pembelajaran bahasa bukanlah sekedar bertujuan untuk memberikan pengetahuan tentang bahasa, akan tetapi lebih dari itu. Pembelajaran bahasa lebih diarahkan agar peserta didik mampu menguasai dan menggunakan bahasa tersebut untuk berkomunikasi dengan baik (Depdiknas 2003, p 12).

Ada empat kompetensi dasar utama dalam proses pembelajaran bahasa yaitu mendengarkan, berbicara, membaca dan menulis. Membaca merupakan salah satu kemampuan berbahasa yang sangat penting. Melalui kegiatan membaca, seseorang bisa memperoleh berbagai informasi, mengembangkan pengetahuan dan kemampuan baik kognitif, afektif maupun psikomotor. Budaya baca bahkan bisa menjadi tolak ukur kemajuan suatu bangsa. Bangsa yang maju mempunyai budaya baca yang baik, sedangkan bangsa-bangsa yang sedang berkembang umumnya budaya baca maupun kemampuan bacanya kurang.

Pembelajaran membaca terutama mulai dari kelas awal memiliki peran strategis untuk menanamkan budaya baca bagi anak-anak. Namun kenyataan yang terjadi adalah minat baca anak-anak kita masih rendah. Pembelajaran bahasa Indonesia di sekolah belum mampu menumbuhkan minat baca, apalagi budaya baca. Berdasarkan survey di beberapa sekolah, pembelajaran membaca awal di kelas 1 SD masih dilakukan secara konvensional, belum memanfaatkan media, guru menjadi sumber pengetahuan bagi siswa. Permasalahan yang terjadi adalah guru kurang memiliki inovasi dan kreativitas dalam pembelajaran membaca awal, sehingga pembelajaran menjadi tidak menarik bagi siswa. Pada akhirnya siswa tidak memiliki minat dan kemampuan baca yang baik.

Media pembelajaran menjadi salah satu alternatif untuk mengatasi masalah ini. Dengan media, siswa dapat lebih memiliki pengalaman belajar yang lebih variatif dan menarik. Dewasa ini media pembelajaran memegang peranan penting di dalam membantu tercapainya tujuan pembelajaran. Belajar mengajar sekarang ini telah bergerak menuju dikuranginya sistem penyampaian dengan ceramah dan berpindah ke arah digunakannya banyak media sebagai salah satu strategi dalam pembelajaran. Pemakaian media pembelajaran bertujuan untuk menyampaikan informasi dalam proses belajar mengajar, mendorong motivasi belajar, meningkatkan efektivitas dan efisiensi, memberi dasar pengalaman konkrit bagi pemikiran yang abstrak serta mempertinggi perhatian peserta didik. Pemakaian media memang sangat penting untuk menjelaskan masalah-masalah materi pelajaran.

Salah satu media pembelajaran yang berkembang saat ini adalah program pembelajaran berbantuan komputer atau sering disebut sebagai Computer Assisted Instruction (CAI). Pembelajaran berbantuan komputer sebagai program instruksional merupakan program yang menggunakan media komputer sebagai alat untuk menyampaikan pesan atau isi kepada peserta didik. Ada beberapa kelebihan dalam pembelajaran berbantuan komputer, di antaranya adalah adanya daya tarik yang dapat menimbulkan minat kepada anak. Daya tarik itu dapat diciptakan dengan pemanfaatan multimedia yang terintegrasi. Selain itu melalui komputer dapat dirancang suatu program pembelajaran dengan adanya interaktivitas di dalamnya.

Pembelajaran berbantuan komputer bisa dimanfaatkan sebagai media untuk membantu pembelajaran membaca yang terintegrasi dengan menulis awal melalui pelajaran bahasa Indonesia di sekolah dasar, sesuai dengan kurikulum 2013 yang tematik integratif. Pelajaran bahasa Indonesia, terutama di kelas awal sekolah dasar strategis untuk mengenalkan konsep-konsep benda secara visual dengan pengenalan kata, baik secara visual maupun auditif. Hal ini bisa dibantu dengan media dengan tampilan yang menarik melalui pembelajaran berbantuan komputer.

Berdasarkan hal tersebut, peneliti sangat tertarik untuk mengembangkan media pembelajaran membaca berbantuan komputer untuk siswa kelas 1 Sekolah 
Dasar, yang layak, menarik, dapat menumbuhkan minat baca dan meningkatkan kemampuan membaca awal.

\section{Membaca sebagai Keterampilan Berbahasa}

Membaca merupakan salah satu dari empat keterampilan berbahasa. Hodgson (dalam Tarigan 1985, p.7) mendefinisikan membaca sebagai proses yang dilakukan serta dipergunakan oleh pembaca untuk memperoleh pesan yang disampaikan penulis melalui bahasa tulis. Dari segi linguistik, membaca merupakan proses penyandian kembali dan pembacaan sandi (decoding). Sandi merupakan lambang tersurat dari suatu makna yang terkandung di dalamnya. Jadi ketika seseorang sedang melakukan kegiatan membaca, ia mengalami proses mental berupa menangkap makna yang terkandung di balik kata-kata ataupun kalimat yang dibacanya.

Dari uraian tersebut dapat dipahami bahwa membaca merupakan suatu keterampilan yang kompleks dan rumit karena melibatkan serangkaian keterampilan-keterampilan yang lebih kecil. Broughton (dalam Tarigan 1985, p 10) menguraikan ada tiga komponen yang terdapat dalam kegiatan membaca, yaitu pengenalan terhadap aksara dan tanda-tanda baca; korelasi aksara beserta tanda-tanda baca dengan unsur-unsur linguistik formal; dan hubungan kedua komponen tersebut dengan makna.

Keterampilan pengenalan aksara dan tanda baca merupakan kemampuan mengenal bentuk-bentuk yang disesuaikan dengan mode berupa gambar, lengkungan, garis, titik dalam pola hubungan yang teratur. Keterampilan mengkorelasi antara aksara dan tanda baca dengan unsur bahasa formal merupakan kemampuan menghubungkan tanda-tanda yang dilihat dengan unsur-unsur bahasa, seperti kata, frasa, kalimat, paragraf, bab, maupun buku, bahkan unsur yang paling dasar berupa bunyi-bunyi tunggal yang disebut fonem.

Keterampilan menghubungkan komponen tanda bahasa, unsur formal bahasa dengan makna merupakan keterampilan yang kompleks mencakup keseluruhan keterampilan membaca, pada hakekatnya merupakan keterampilan intelektual menghubungkan tanda-tanda melalui unsur bahasa formal yaitu kata-kata sebagai bunyi dengan makna yang dilambangkan oleh kata-kata tersebut.

Lebih lanjut Broughton (dalam Tarigan 1985, p11) menguraikan ada dua aspek penting dalam membaca, yaitu keterampilan yang bersifat mekanis (mechanical skills) yang merupakan keterampilan yang lebih rendah. Aspek ini mencakup: (1) pengenalan bentuk huruf, (2) pengenalan unsur-unsur linguistik berupa fonem, kata, frasa, klausa, kalimat dan lain-lain, (3) pengenalan hubungan pola ejaan dan bunyi, dan (4) kecepatan membaca bertaraf lambat.

Aspek yang kedua adalah keterampilan yang bersifat pemahaman (comprehension skills) yang dapat dianggap berada pada urutan yang lebih tinggi. Aspek ini mencakup: (1) memahami pengertian sederhana leksikal, gramatikal, retorikal, (2) memahami signifikansi atau makna, antara lain maksud dan tujuan pengarang, relevansi keadaan kebudayaan, reaksi pembaca, (3) evaluasi atau penilaian baik isi maupun bentuk, (4) kecepatan membaca yang fleksibel, mudah disesuaikan dengan keadaan. Untuk mencapai kemampuan mekanis, aktivitas yang paling sesuai adalah dengan membaca nyaring atau bersuara, sedangkan untuk mencapai kemampuan pemahaman, maka aktivitas yang paling tepat adalah dengan membaca tak bersuara atau membaca dalam hati.

\section{Pembelajaran Membaca di Sekolah Dasar}

Departemen Pendidikan Nasional (2003) menetapkan standar kompetensi pembelajaran membaca di sekolah dasar. Standar kompetensi tersebut adalah menggunakan berbagai jenis membaca untuk memahami wacana berupa petunjuk, teks panjang, dan berbagai karya sastra untuk anak berbentuk puisi, dongeng, pantun, percakapan, cerita dan drama. 
Ada pun ruang lingkup pembelajaran membaca untuk SD adalah membaca huruf, suku kata, kata, kalimat, paragraf, bebagai teks bacaan, denah petunjuk, tata tertib, pengumuman, kamus, ensiklopedia serta mengapresiasi dan berekspresi sastra melalui kegiatan hasil sastra berupa dongeng, cerita anak, cerita rakyat, cerita binatang, puisi anak, syair lagu, pantun, dan drama anak. kompetensi membaca juga diarahkan untuk menumbuhkan budaya baca

Pencapaian standar kompetensi tersebut tentunya dilakukan melalui tahapantahapan sesuai dengan tingkat perkembangan intelektual siswa berdasarkan jenjang kelasnya. Untuk siswa kelas I standar kompetensi yang harus dicapai adalah mampu membaca dan memahami teks pendek dengan cara membaca lancar (bersuara) dan membaca nyaring beberapa kalimat sederhana.

\section{Penelitian Pengembangan}

Sugiyono (2006, p.407) menyatakan bahwa penelitian pengembangan adalah penelitian yang bertujuan untuk menghasilkan produk tertentu, dan menguji keefektifan produk tersebut. Produk-produk pendidikan menurut Sugiyono berkaitan dengan kurikulum, metode, media, kompetensi tenaga pengajar, sistem evaluasi, model uji kompetensi, penataan ruang kelas untuk model pembelajaran tertentu, model manajemen pendidikan, sistem pembinaan pegawai, sistem penggajian dan lain-lain.

Sukmadinata (2007, p.164) menyatakan bahwa yang dimaksud dengan penelitian dan pengembangan adalah suatu proses atau langkah-langkah untuk mengembangkan suau produk baru atau menyempurnakan produk yang telah ada, yang dapat dipertanggungjawabkan. Produk tersebut tidak selalu berbentuk benda atau perangkat keras (hardware), tetapi juga perangkat lunak (software)

Untuk dapat menghasilkan produk yang baik dan efektif, penelitian pengembangan perlu dilakukan dengan tahaptahap tertentu. Tahap-tahap penelitian pengembangan, menurut Borg\& Gall (via
Setyosari 2012, p.228) adalah 1) melakukan penelitian pendahuluan dan pengumpulan informasi awal, yang meliputi kajian pustaka, pengamatan atau observasi kelas, dan persiapan laporan awal. Penelitian awal atau analisis kebutuhan sangat penting dilakukan guna memperoleh informasi awal untuk melakukan pengembangan.. Hal ini bisa dilakukan dengan pengamatan kelas untuk melihat kondisi riil lapangan. Kajian pustaka dan termasuk literatur pendukung terkait sangat diperlukan sebagai landasan melakukan pengembangan; 2) perencanaan yang meliputi penetapan tujuan, perkiraan dana, waktu, tenaga, ketersediaan tempat uji coba; 3) pengembangan bentuk awal dan revisi produk; 4) uji lapangan awal; 5) revisi produk; 6) uji lapangan utama; 7) revisi produk; 8) uji lapangan operasional; 9) revisi produk akhir; 10) diseminasi dan implementasi.

Sedangkan menurut Dick \& Carey (2005, pp 6-8) komponen-komponen dalam pengembangan meliputi: 1) identifikasi tujuan pembelajaran; 2) analisis pembelajaran; 3) analisis pebelajar dan konteks; 4) merumuskan tujuan; 5) mengembangkan Instrumen; 6) mengembangkan strategi pembelajaran; 7) mengembangkan dan memilih bahan pembelajaran; 8) merancang dan melakukan evaluasi formatif; 9) melakukan revisi; 10) melakukan evaluasi sumatif

Menurut Wasis D Dwiyogo (2004, p.6) langkah-langkah tersebut bukan merupakan langkah baku yang harus diikuti. Setiap pengembang boleh memilih dan menentukan sendiri langkah yang akan ditempuh berdasarkan kondisi yang dihadapi. Menurutnya yang terpenting dalam penelitian pengembangan, harus melalui prosedur yang meliputi lima langkah, Yaitu (1) melakukan analisis produk yang akan dikembangkan; (2) mengembangkan produk awal; (3) validasi ahli; (4) uji coba lapangan; (5) revisi produk.

Dari beberapa penjelasan tersebut dapat disimpulkan bahwa penelitian pengembangan merupakan jenis penelitian yang bertujuan untuk menghasilkan sebuah produk pembelajaran dengan ta- 
hapan analisis kebutuhan, pengembangan produk, evaluasi produk, revisi dan penyebaran produk.

Media Pembelajaran Berbantuan Komputer (MPBK)

Secara etimologis, 'media' berasal dari bahasa Latin medium yang berarti perantara atau sesuatu yang dipakai untuk menghantarkan, menyampaikan atau membawa sesuatu (Munir 2012, p.2). Dalam perkembangannya kata 'media' diartikan sebagai segala bentuk saluran yang dipergunakan untuk menyampaikan pesan atau informasi. (AECT 1977). Heinich dkk (2005, p 9) menyatakan bahwa: “A medium (plural media) is a channel of communication, example include film, television, diagram, printed materials, computers, and instructors". Dalam kaitannya dengan proses pembelajaran, media diartikan oleh Gagne sebagai komponen dalam lingkungan peserta didik yang dapat merangsang peserta didik untuk belajar.

Dari berbagai batasan tersebut dapat dirumuskan bahwa media pembelajaran adalah segala sesuatu yang dapat dipergunakan untuk menyalurkan pesan dan dapat merangsang pikiran, membangkitkan semangat, perhatian dan kemauan peserta didik sehingga dapat mendorong terjadinya proses pembelajaran pada diri peserta didik.

Komputer merupakan teknologi yang dapat digunakan untuk berbagai kepentingan dalam berbagai aspek kehidupan. Komputer untuk pembelajaran dewasa ini berkembang cukup pesat. Hal itu muncul dalam berbagai program misalnya CAL (Computer Assited Learning), CAI (Computer Assited Instruction), CBI (Computer Based Instruction) dan sebagainya.

Pembelajaran berbantuan komputer sering disebut sebagai Computer Assisted Instruction (CAI). Definisi yang mudah untuk dipahami sesuai dengan konteks teknologi pendidikan adalah sebagaimana yang dikemukakan oleh Criswell (1989, p.1) yang menyatakan bahwa" The term computer-based instruction (CBI refers to any use of a computer to present instructional material, provide for active participation of the student, and respon to student action"

Berdasarkan definisi tersebut, dalam proses pembelajaran berbantuan komputer terjadi interaksi langsung antara peserta didik dengan komputer. Interaksi antara peserta didik dengan komputer ini terjadi secara individual, sehingga apa yang dialami oleh peserta didik yang satu akan berbeda dengan apa yang dialami peserta didik yang lain. Namun demikian interaksi tersebut bersifat sederhana dan mekanikal, tidak seperti interaksi antarmanusia yang sifatnya lebih kompleks.

\section{Metode Penelitian}

Penelitian ini merupakan jenis penelitian pengembangan. Dipilihnya jenis penelitian ini karena penelitian ini berusaha mengembangkan suatu produk berupa media pembelajaran dan mengujinya sehingga hasilnya diharapkan dapat membantu mengatasi permasalahan pembelajaran. Prosedur yang dilakukan dalam penelitian ini menggunakan prosedur penelitian pengembangan oleh Borg and Gall (1989, p 784) yang dipadu dengan model Dick and Carey (1985, p 6) dan Crisswell (1989, p 50).

Dari kajian teori yang ada, modifikasi prosedur pengembangan menurut Borg \& Gall, Dick \& Carey dan Criswell (BDC) diuraikan dalam penjelasan berikut:

\section{Pengumpulan Informasi Awal}

Pengumpulan informasi awal ini berupa (a) studi pustaka, yaitu mengkaji teori-teori tentang membaca, pembelajaran membaca, hasil-hasil penelitian yang relevan dengan penelitian yang akan dilakukan. (b) studi lapangan untuk mendapatkan masukan mengenai media pembelajaran yang perlu dikembangkan, melalui survey dengan guru tentang materi pelajaran yang perlu dikembangkan dalam bentuk software pembelajaran.

Mengembangkan Materi Pembelajaran

Menetapkan Standar Kompetensi

Standar kompetensi dalam pembelajaran ini adalah peserta didik mampu me- 
mahami teks pendek dengan membaca nyaring.

\section{Menetapkan Kompetensi Dasar}

Kompetensi dasar dalam pembelajaran ini adalah membaca nyaring kata dengan lafal yang tepat.

\section{Merumuskan indikator}

Indikator ketercapaian dalam CD pembelajaran ini adalah peserta didik memiliki kemampuan membaca nyaring kata beserta konsep benda secara visual dan auditif, serta memiliki rasa senang membaca.

\section{Mengembangkan materi pembelajaran}

Materi pembelajaran adalah materi pokok yang harus dipelajari peserta didik sebagai sarana pencapaian kompetensi dasar yang akan dinilai menggunakan instrumen penilaian yang disusun berdasarkan indikator ketercapaian kompetensi. Kompetensi yang akan dicapai dalam pembelajaran ini adalah peserta didik memiliki kemampuan membaca nyaring kata beserta konsep benda secara visual dan auditif serta memiliki rasa senang membaca.

\section{Merumuskan bentuk penilaian}

Dalam CD pembelajaran ini penilaian diberikan ketika sajian berlangsung dalam bentuk soal-soal latihan.

\section{Mengembangkan Produk}

Membuat desain setiap frame

Bahan-bahan yang sudah ditetapkan kemudian dituangkan ke dalam bentuk storybord. Storyboard merupakan rancangan program yang menjelaskan tampilan tiap-tiap slide. Setiap tampilan mempunyai storyboard sendiri. Storyboard CD pembelajaran ini memuat keterangan tentang teks, sound, background, button, gambar, dan animasi yang diperlukan pada masing-masing tampilan

\section{Memilih Bahasa Pemrograman}

Bahasa pemrograman yang dipakai adalah yang terdapat dalam software aplikasi, yaitu Lectora.
Mengumpulkan dan memproduksi bahan yang terkait

Mengumpulkan bahan mencakup kegiatan (1) mengembangkan materi menjadi CD pembelajaran; (2) mengolah bahan menjadi bentuk-bentuk yang dapat membantu pemahaman peserta didik, misalnya gambar, animasi, suara; (3) mencari sumbersumber yang relevan yang dapat memudahkan peserta didik mencapai kompetensi.

\section{Melakukan evaluasi}

Validasi

Validasi produk dalam pengembangan ini adalah kegiatan yang dilakukan dalam rangka memperoleh $\mathrm{CD}$ pembelajaran yang berkualitas baik dari segi isi, pembelajaran maupun kemediaan. Penilaian dan saran-saran disajikan sebagai dasar dalam melakukan revisi.

Revisi

Revisi dilakukan setelah angket penilaian dan hasil diskusi dengan para ahli dan pemanfaat dilakukan.

Uji coba produk

\section{Desain Uji coba}

Uji coba produk dilakukan untuk mendapatkan data yang akan digunakan untuk sebagai dasar untuk melakukan revisi produk multimedia pembelajaran untuk melatih kemampuan membaca awal untuk anak kelas 1 sekolah dasar. Uji coba produk dalam penelitian ini dilakukan dalam tiga tahap yaitu: (1) uji coba satu-satu; (2) uji coba kelompok kecil; (3) uji coba kelompok besar.

Subjek Uji coba

Uji coba perseorangan ini dilakukan setelah adanya masukan dari ahli ahli materi dan ahli media dan guru sebagai pemanfaat. Setelah uji coba tahap pertama ini kemudian dilakukan revisi tahap I guna perbaikan menuju uji coba tahap kedua.

Uji coba kedua adalah ujicoba kelompok kecil yang terdir dari 10 peserta didik, setelah itu dilakukan revisi tahap II guna perbaikan menuju uji coba tahap ketiga. 
Uji coba tahap ketiga adalah uji coba lapangan. Pada tahap ini data yang diperoleh dianalisis untuk menentukan kualitas produk sehingga diperoleh kesimpulan produk ini layak digunakan secara luas atau tidak.

Jenis Data

Jenis data yang akan digali meliputi empat hal, yaitu: (a) Ketepatan rancangan dan media dari ahli desain pembelajaran dan ahli media (b) Ketepatan isi software media diperoleh dari ahli materi bidang studi (c) kemenarikan bahan ajar yakni memotivasi belajar dan penghargaan atau apresiasi peserta didik.

\section{Instrumen Pengumpul Data}

Untuk menggali data mengenai ketepatan rancangan dan media peneliti melakukan diskusi dan menyerahkan produk yang dibuat kepada ahli materi dan ahli media supaya di-review menggunakan kuesioner.

Untuk menggali kualitas tampilan dan kualitas penyajian, digunakan kuesioner dengan skala likert dan didiskusikan dengan responden kelompok kecil dan untuk kelompok besar tidak perlu diskusi.

Untuk melihat aspek daya tarik, dilakukan dengan kuesioner yang dibuat dengan langkah-langkah: analisis dokumen, pembuatan tabel kisi-kisi, konsultasi dengan ahli, dan penulisan instrumen.

Instrumen untuk pengumpulan data adalah lembar kuesioner, masingmasing untuk ahli media, ahli materi, guru dan untuk peserta didik. Instrumen dikembangkan dan diformulasikan dari teori evaluasi media dari beberapa ahli, diantaranya Hannafin, Criswell dan Rob Philip.

Lembar kuesioner disusun dengan validitas logis yang dijabarkan dalam beberapa aspek dan indikator dengan kriteria seperti tabel.

\section{Teknik Analisis Data}

Data yang diperoleh dari responden berdasarkan lembar kuesioner yang dibagikan dianalisis menggunakan teknik statistik deskripstif berdasarkan masingmasing variabel. Untuk keperluan analisis kuantitatif maka jawaban yang diperoleh diberi skor dengan kriteria dan dikonversikan menggunakan skala 5 sebagai berikut.

Tabel 1. Konversi data kuantitatif ke kualitatif

\begin{tabular}{|c|c|c|c|}
\hline \multirow[t]{2}{*}{ Nilai } & \multirow[t]{2}{*}{ Kriteria } & \multicolumn{2}{|c|}{ Skor } \\
\hline & & Rumus & Perhitungan \\
\hline 5 & $\begin{array}{c}\text { Sangat } \\
\text { baik }\end{array}$ & $X>X i+1,80$ Sbi & $X>4,21$ \\
\hline 4 & Baik & $\begin{array}{l}X i+0,60 \text { SBi }<X \leq \\
X i+1,80 \text { Sbi }\end{array}$ & $3,40<X \leq 4,21$ \\
\hline 3 & Cukup & $\begin{array}{l}X i-0,60 \text { SBi }<X \leq \\
X i+0,60 \text { Sbi }\end{array}$ & $2,60<X \leq 3,40$ \\
\hline 2 & Tidak baik & $\begin{array}{l}X i-1,80 \text { SBi }<X \leq \\
X i-0,60 \text { Sbi }\end{array}$ & $1,79<X \leq 2,60$ \\
\hline 1 & $\begin{array}{c}\text { Sangat } \\
\text { tidak baik }\end{array}$ & $\mathrm{X} \leq \mathrm{Xi}-1,80$ Sbi & $X \leq 1,79$ \\
\hline
\end{tabular}

Rerata ideal $(\mathrm{Xi})=\frac{1}{2}($ skor maksimal ideal + skor minimal ideal)

Simpangan Baku ideal $(\mathrm{SBi})=\frac{1}{6}($ skor maksimal ideal - skor minimal ideal)

$\mathrm{X}=$ skor empiris

Untuk mendapatkan data rerata hasil penilaian yang akan digunakan sebagai kesimpulan, digunakan rumus:

Rerata Penilaian $=\frac{\text { Total Penilaian }}{\sum \text { Aspek yang diamati } \times \sum \text { Siswa }}$

\section{Hasil Penelitian dan Pembahasan}

Penelitian ini menggunakan enam macam data, yaitu: data hasil validasi ahli materi, data hasil validasi ahli media, data hasil validasi guru, data hasil uji coba satusatu, data hasil uji coba kelompok kecil, data hasil uji kelompok besar. Data-data yang diperoleh dalam penelitian ini adalah data-data yang berupa penilaian dari ahli materi, ahli media, guru, dan anak sebagai pengguna ketika anak menggunakan multimedia yang dikembangkan oleh peneliti. Data validasi dari ahli materi, ahli media dan guru merupakan data awal yang digunakan untuk melihat dan merevisi produk sebelum dilakukan uji coba lapangan.

Uji coba lapangan dilaksanakan di SD Padokan 2 Kasihan Bantul, Yogyakarta. Dengan menggunakan data ujicoba satusatu, diperoleh informasi dari setiap komponen multimedia yang masih menjadi kendala ketika produk tersebut diujicobakan satu-satu. Uji kelompok kecil dilaksa- 
nakan setelah dilakukan revisi berdasarkan hasil ujicoba satu-satu, melalui uji kelompok kecil ini diketahui sejauh mana kelayakan multimedia ini untuk dilakukan ujicoba kelompok besar. Ujicoba kelompok besar dilaksanakan setelah dilakukan revisi berdasarkan hasil yang diperoleh dalam ujicoba kelompok kecil. Uji kelompok besar ini menghasilkan data-data untuk mengukur kelayakan dari produk yang dikembangkan dan efektivitas media melalui pengukuran hasil belajar. Berikut hasil validasi ahli materi terhadap multimedia yang dikembangkan oleh peneliti.

Kriteria akhir dari aspek dalam Tabel 2 diperoleh berdasarkan hasil konversi data kuantitatif ke data kualitatif dengan skala 5 disajikan pada Tabel 3.

Tabel 2. Hasil validasi dari ahli materi

\begin{tabular}{|c|c|c|c|c|}
\hline \multirow{2}{*}{ No } & \multirow{2}{*}{ Indikator } & \multicolumn{3}{|c|}{ Penilaian } \\
\hline & & 23 & 4 & 5 \\
\hline \multicolumn{4}{|c|}{ 1. Urutan materi } & $\sqrt{ }$ \\
\hline \multicolumn{2}{|c|}{ 2. Cakupan materi } & & $\sqrt{ }$ & \\
\hline \multicolumn{2}{|c|}{ 3. Kejelasan Materi } & & & $\sqrt{ }$ \\
\hline \multicolumn{2}{|c|}{ 4. Urgensi tiap materi } & & $\sqrt{ }$ & \\
\hline \multicolumn{2}{|c|}{$\begin{array}{l}\text { 5. Aktualisasi (up to date) } \\
\text { materi }\end{array}$} & & $\sqrt{ }$ & \\
\hline \multicolumn{2}{|c|}{ 6. Kejelasan sasaran } & & & $\sqrt{ }$ \\
\hline \multicolumn{2}{|c|}{$\begin{array}{l}\text { 7. Kejelasan tujuan } \\
\text { pembelajaran }\end{array}$} & & & $\sqrt{ }$ \\
\hline \multicolumn{2}{|c|}{ 8. Struktur materi } & & & $\sqrt{ }$ \\
\hline \multicolumn{2}{|c|}{ 9. Ketepatan evaluasi } & & & $\sqrt{ }$ \\
\hline \multicolumn{2}{|c|}{$\begin{array}{l}\text { 10. Konsisten antara tujuan } \\
\text { dan latihan }\end{array}$} & & $\sqrt{ }$ & \\
\hline \multicolumn{2}{|c|}{ Jumlah (Skala $\times \sum$ Frekuensi) } & & 16 & 30 \\
\hline \multicolumn{2}{|c|}{ Total Penilaian } & 4 & & \\
\hline \multicolumn{2}{|c|}{ Rerata Penilaian } & 4 & & \\
\hline \multicolumn{2}{|c|}{ Kesimpulan Penilaian } & Sanga & Baik & \\
\hline \multicolumn{5}{|c|}{$\begin{array}{l}5=\text { Sangat Baik, } 4=\text { Baik, } 3=\text { Cukup, } 2= \\
\text { Kurang, } 1=\text { Sangat Kurang }\end{array}$} \\
\hline \multicolumn{5}{|c|}{$\begin{array}{l}\text { Tabel 3. Konversi Data Kuantitatif ke Data } \\
\text { Kualitatif dengan Skala } 5\end{array}$} \\
\hline $\begin{array}{c}\text { Data } \\
\text { Kuantitatif } \\
\end{array}$ & \multicolumn{2}{|l|}{ Rentang } & \multicolumn{2}{|c|}{$\begin{array}{c}\text { Data } \\
\text { Kualitatif } \\
\end{array}$} \\
\hline 5 & \multicolumn{2}{|l|}{$X>X i+1,80$ Sbi } & \multicolumn{2}{|c|}{$\begin{array}{l}\text { Sangat } \\
\text { baik }\end{array}$} \\
\hline 4 & \multicolumn{2}{|c|}{$X i+0,60$ Sbi $<X \leq X i+1,80$ Sbi } & \multicolumn{2}{|c|}{ Baik } \\
\hline 3 & \multicolumn{2}{|c|}{$\mathrm{X} \mathrm{i}-0,60$ Sbi $<\mathrm{X} \leq \mathrm{Xi}+0,60$ Sbi } & \multicolumn{2}{|c|}{ Cukup } \\
\hline 2 & \multicolumn{2}{|c|}{$\mathrm{Xi}-1,80$ Sbi $<\mathrm{X} \leq \mathrm{Xi}-0,60$ Sbi } & \multicolumn{2}{|c|}{ Kurang } \\
\hline 1 & \multicolumn{2}{|l|}{$X \leq X i-1,80 S b i$} & \multicolumn{2}{|c|}{$\begin{array}{l}\text { Sangat } \\
\text { kurang }\end{array}$} \\
\hline
\end{tabular}

Keterangan:

$\mathrm{Xi}_{\text {(Rerata Ideal) }}=\frac{1}{2}$ (skor mak ideal + skor min ideal $)$ Sbi $\left(\right.$ Simpangan baku ideal) $=\frac{1}{6}$ (skor mak ideal - skor min ideal)

$\mathrm{X}=$ Skor Aktual

Berdasarkan rumus konversi data di atas, maka setelah didapatkan data-data kuantitatif, untuk mengubahnya ke dalam data kualitatif pada pengembangan ini diterapkan konversi sebagai berikut:

Skor Mak $=5$

Skor Min $=1$

$\mathrm{Xi}=\frac{1}{2}(5+1)=3$

Sbi $=\frac{1}{6}(5-1)=0,6$

Skala $5=X>3+(1,8 \times 0,6)=X>3+1,08=X>4,08$

Skala $4=3+(0,6 \times 0,6)<X \leq 4,08=3+0,36<X \leq$ $4,08=3,36<X \leq 4,08$

Skala $3=3-0,36<X \leq 3,36=2,64<X \leq 3,36$

Skala $2=3-(1,8 \times 0,6)<X \leq 2,64$

$=3-1,08<x \leq 2,64$

$=1,92<X \leq 2,64$

Skala $1=\mathrm{X} \leq 1,92$

Atas dasar perhitungan di atas maka konversi data kuantitatif ke data kualitatif skala 5 dapat disederhanakan sebagai berikut.

Tabel 4. Pedoman Hasil Konversi Data Kuantitatif ke Data Kualitatif

\begin{tabular}{ccc}
\hline Skor & Rentang & Kriteria \\
\hline 5 & $X>4,08$ & Sangat baik \\
4 & $3,36<X \leq 4,08$ & Baik \\
3 & $2,64<X \leq 3,36$ & Cukup \\
2 & $1,92<X \leq 2,64$ & Kurang \\
1 & $X \leq 1,92$ & Sangat kurang \\
\hline
\end{tabular}

Bila dikonversikan berdasarkan Tabel 4, maka hasil penilaian dari ahli materi secara keseluruhan adalah sangat baik, hal ini dilihat dari rerata nilai yang diperoleh sebesar 4,6 yang dikonversikan ke dalam data kualitatif dengan mengacu pada tabel nilai konversi adalah sangat baik, karena rerata penilaian 4,6 berada pada skor 5 dalam rentang $X>X i+1,80$ Sbi.

\section{Deskripsi Data Validasi Ahli Media}

Adapun hasil penilaian yang diberikan secara keseluruhan oleh ahli media dapat dilihat pada Tabel 5 . 
Tabel 5. Hasil validasi dari ahli media

\begin{tabular}{|c|c|c|c|}
\hline \multirow{2}{*}{ No } & \multirow{2}{*}{ Indikator } & \multicolumn{2}{|c|}{ Penilaian } \\
\hline & & 23 & 4 \\
\hline & Struktur program & & $\sqrt{ }$ \\
\hline 2. & Logika berpikir & & $\sqrt{ }$ \\
\hline & $\begin{array}{l}\text { Interaksi pengguna } \\
\text { dengan media }\end{array}$ & & \\
\hline & Pemberian contoh & & \\
\hline & Penggunaan bahasa & & $\sqrt{ }$ \\
\hline & Tampilan desain & & \\
\hline & Grafis background & & $\sqrt{ }$ \\
\hline & Ukuran teks & & \\
\hline & Penggunaan animasi & & $\sqrt{ }$ \\
\hline & Penggunaan warna & & $\sqrt{ }$ \\
\hline & $\begin{array}{l}\text { Penggunaan gambar } \\
\text { yang mendukung }\end{array}$ & & $\sqrt{ }$ \\
\hline 12. & Penggunaan musik & & \\
\hline 13. & Penggunaan sound effect & & $\sqrt{ }$ \\
\hline & Penggunaan suara & & 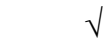 \\
\hline 15. & Kreatifitas & & $\sqrt{ }$ \\
\hline 16. & Urutan penyajian & & \\
\hline & $\begin{array}{l}\text { Pergantian gambar dari } \\
\text { frame ke frame }\end{array}$ & & $\sqrt{ }$ \\
\hline & amlah (Skala $\times \sum$ Frekuensi) & & 3640 \\
\hline & tal Penilaian & 76 & \\
\hline Rer & rata Penilaian & 4,47 & \\
\hline Kes & simpulan Penilaian & Sangat & Baik \\
\hline
\end{tabular}

Hasil penilaian yang diberikan oleh ahli media pada evaluasi tahap dua menunjukkan bahwa secara keseluruhan multimedia yang dikembangkan oleh peneliti dapat disimpulkan sudah sangat baik, hal ini dilihat dari rerata nilai yang diperoleh sebesar 4,47 yang dikonversikan ke dalam data kualitatif dengan mengacu pada tabel nilai konversi adalah sangat baik, karena rerata penilaian 4,47 berada pada skor 5 dalam rentang $X>X i+1,80$ Sbi.

\section{Deskripsi Data Validasi Guru}

Validasi oleh guru dilakukan setelah dinyatakan layak oleh ahli media. Data hasil validasi guru didapatkan melalui satu tahapan, dan diperoleh data yang disajikan pada Tabel 6.

Dari data yang diperoleh berdasarka instrumen untuk guru, diperoleh komentar bahwa program sudah bagus, dan menarik. Diperoleh juga masukan untuk mengembangkan program sehingga materi tidak hanya terbatas pada nama-nama buah dan binatang saja.

Tabel 6. Hasil validasi dari guru

\begin{tabular}{|c|c|c|c|c|c|c|}
\hline \multirow{2}{*}{ No } & \multirow{2}{*}{ Indikator } & \multicolumn{5}{|c|}{ Penilaian } \\
\hline & & 1 & 2 & 3 & 4 & 5 \\
\hline 1. & $\begin{array}{l}\text { Sesuai dengan tujuan } \\
\text { yang dirumuskan }\end{array}$ & & & & & $\sqrt{ }$ \\
\hline 2. & $\begin{array}{l}\text { Sesuai dengan tingkat } \\
\text { kemampuan }\end{array}$ & & & & & $\sqrt{ }$ \\
\hline 3. & $\begin{array}{l}\text { Menggunakan bahasa } \\
\text { yang mudah dipahami }\end{array}$ & & & & & $\sqrt{ }$ \\
\hline 4. & Ilustrasi & & & & & $\sqrt{ }$ \\
\hline 5. & Kualitas evaluasi & & & & & $\sqrt{ }$ \\
\hline 6. & Kualitas penyajian & & & & & $\sqrt{ }$ \\
\hline 7. & Urutan penyajian & & & & & $\sqrt{ }$ \\
\hline 8. & Interaktivitas media & & & & & $\sqrt{ }$ \\
\hline 9. & Umpan balik & & & & $\sqrt{ }$ & \\
\hline 10. & Pemberian motivasi & & & & $\sqrt{ }$ & \\
\hline 11. & Pengayaan materi & & & & $\sqrt{ }$ & \\
\hline 12. & Kejelasan petunjuk & & & & & $\sqrt{ }$ \\
\hline 13. & $\begin{array}{l}\text { pemilihan huruf yang } \\
\text { digunakan }\end{array}$ & & & & & $\sqrt{ }$ \\
\hline 14. & $\begin{array}{l}\text { ukuran huruf yang } \\
\text { digunakan }\end{array}$ & & & & & $\sqrt{ }$ \\
\hline 15. & Sajian animasi & & & & & $\sqrt{ }$ \\
\hline 16. & Komposisi warna & & & & & $\sqrt{ }$ \\
\hline 17. & Kejelasan suara & & & & & $\sqrt{ }$ \\
\hline 18. & Sound effect & & & & & $\sqrt{ }$ \\
\hline 19. & $\begin{array}{l}\text { Kemudahan } \\
\text { penggunaan software }\end{array}$ & & & & & $\sqrt{ }$ \\
\hline Juml & ah (Skala x $\sum$ Frekuensi) & & & & 12 & 80 \\
\hline Tota & Penilaian & & & 92 & & \\
\hline Rera & ta Penilaian & & & 4,84 & & \\
\hline Kesi & mpulan Penilaian & & San & gat & Baik & \\
\hline
\end{tabular}

\section{Deskripsi Data Uji Coba Satu-Satu}

Uji lapangan terbatas dilakukan setelah multimedia divalidasi oleh ahli materi, ahli media, dan guru serta dinyatakan layak untuk dilakukan uji coba lapangan.

Uji coba satu-satu melibatkan 3 orang siswa kelas satu dari SD Negeri Padokan 2 Kasihan Bantul. Uji coba satusatu dilakukan pada tanggal 27 Juni 2013. Berdasarkan observasi yang dilakukan terhadap anak, didapatkan hasil yang disajikan pada Tabel 7. 
Berdasarkan data hasil ujicoba satusatu, secara keseluruhan dapat disimpulkan bahwa multimedia pembelajaran yang dikembangkan oleh peneliti sudah baik. Hal ini dilihat dari jumlah rerata skor setelah dikonversikan ke dalam data kualitatif.

Tabel 7. Data hasil observasi anak pada uji coba satu-satu

\begin{tabular}{|c|c|c|c|c|c|}
\hline Aspek yang Diamati & 1 & 2 & 3 & 4 & 5 \\
\hline $\begin{array}{l}\text { 1. Kesenangan siswa } \\
\text { terhadap media }\end{array}$ & 0 & 0 & 0 & 3 & 0 \\
\hline $\begin{array}{l}\text { 2. Tanggapan terhadap } \\
\text { musik }\end{array}$ & 0 & 0 & 0 & 3 & 0 \\
\hline $\begin{array}{l}\text { 3. Tanggapan terhadap } \\
\text { gambar }\end{array}$ & 0 & 0 & 0 & 3 & 0 \\
\hline $\begin{array}{l}\text { 4. Tanggapan terhadap } \\
\text { evaluasi }\end{array}$ & 0 & 0 & 1 & 2 & 0 \\
\hline $\begin{array}{l}\text { 5. Tangapan terhadap } \\
\text { kemudahan media }\end{array}$ & 0 & 0 & 0 & 3 & 0 \\
\hline 6. Tanggapan terhadap isi & 0 & 0 & 1 & 2 & 0 \\
\hline $\begin{array}{l}\text { 7. Tanggapan terhadap } \\
\text { pengisi suara }\end{array}$ & 0 & 1 & 0 & 2 & 0 \\
\hline $\begin{array}{l}\text { 8. Tangapan terhadap } \\
\text { Tulisan }\end{array}$ & 0 & 0 & 0 & 2 & 1 \\
\hline Jumlah (Skala x $\sum$ Frekuensi) & 0 & 2 & 6 & 80 & 5 \\
\hline Total Penilaian & & & 93 & & \\
\hline Rerata Penilaian & & & 3,8 & & \\
\hline Kesimpulan Penilaian & & & Bail & & \\
\hline
\end{tabular}

Deskripsi Data Ujicoba Kelompok Kecil

Berdasarkan hasil uji coba, multimedia yang dikembangkan oleh peneliti layak untuk diujikan ke dalam ujicoba kelompok kecil. Uji coba kelompok kecil ini melibatkan 10 orang anak dari SD Padokan 2 Kasihan Banguntapan Bantul.

Uji coba kelompok kecil ini dilaksanakan pada tanggal 30 Juni 2013. Dari uji coba kelompok kecil ini menghasilkan satu jenis data, yaitu data observasi terhadap anak saat menggunakan multimedia yang dikembangkan. Adapun data hasil uji coba kelompk kecil tersebut disajikan dalam Tabel 8.

Data hasil observasi yang dilakukan terhadap anak dalam menggunakan multimedia yang dikembangkan secara keseluruhan didapatkan kesimpulan sangat baik.
Tabel 8. Data pada ujicoba kelompok kecil

\begin{tabular}{|c|c|c|c|c|c|c|}
\hline No & Aspek yang Diamati & 1 & 2 & 3 & 4 & 5 \\
\hline 1. & $\begin{array}{l}\text { Kesenangan siswa } \\
\text { terhadap media }\end{array}$ & 0 & 0 & 0 & 1 & \\
\hline 2. & $\begin{array}{l}\text { Tanggapan terhadap } \\
\text { musik }\end{array}$ & 0 & 0 & 0 & 4 & \\
\hline 3. & $\begin{array}{l}\text { Tanggapan terhadap } \\
\text { gambar }\end{array}$ & 0 & 0 & 0 & 3 & \\
\hline 4. & $\begin{array}{l}\text { Tanggapan terhadap } \\
\text { evaluasi }\end{array}$ & 0 & 0 & 0 & 2 & \\
\hline 5. & $\begin{array}{l}\text { Tangapan terhadap } \\
\text { kemudahan media }\end{array}$ & 0 & 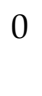 & 0 & 1 & \\
\hline 6. & Tanggapan terhadap isi & 0 & 0 & 0 & 1 & \\
\hline 7. & $\begin{array}{l}\text { Tanggapan terhadap } \\
\text { pengisi suara }\end{array}$ & 0 & 0 & 0 & 1 & \\
\hline 8. & $\begin{array}{l}\text { Tangapan terhadap } \\
\text { Tulisan }\end{array}$ & 0 & 0 & 0 & 1 & \\
\hline Juml & ah (Skala $\times \sum$ Frekuensi) & & & 0 & 56 & \\
\hline & Total Penilaian & & & 386 & & \\
\hline & Rerata Penilaian & & & 4,82 & & \\
\hline
\end{tabular}

Deskripsi Data Ujicoba Kelompok Besar

Ujicoba kelompok besar dilakukan setelah dilakukan revisi berdasarkan analisis data dari hasil ujicoba kelompok kecil. Ujicoba kelompok besar dilaksanakan dengan melibatkan 20 siswa SD Negeri 2 Padokan Kasihan Bantul. Ujicoba kelompok besar ini dilaksanakan pada tanggal 3 Juli. 2013.

Uji Kelompok besar menghasilkan dua jenis data, yaitu data hasil observasi terhadap anak dan efektivitas media untuk meningkatkan kemampuan baca anak dalam bentuk hasik pretes postes. Data hasil ujicoba kelompok besar ini yang nantinya dijadikan pijakan untuk melakukan revisi produk akhir. Adapun data yang diperoleh dari hasil observasi pada ujicoba kelompok besar disajikan dalam Tabel 9.

Data hasil observasi pada ujicoba kelompok besar menunjukkan rerata 4,85 yang bila dikonversikan ke dalam data kualitatif didapatkan kesimpulan sangat baik.

Adapun data yang diperoleh untuk mengetahui tingkat efektivitas media dalam meningkatkan kemampuan membaca siswa adalah dalam bentuk hasil pretes postes disajikan pada Tabel 10 . 
Tabel 9. Data hasil observasi anak pada ujicoba kelompok besar

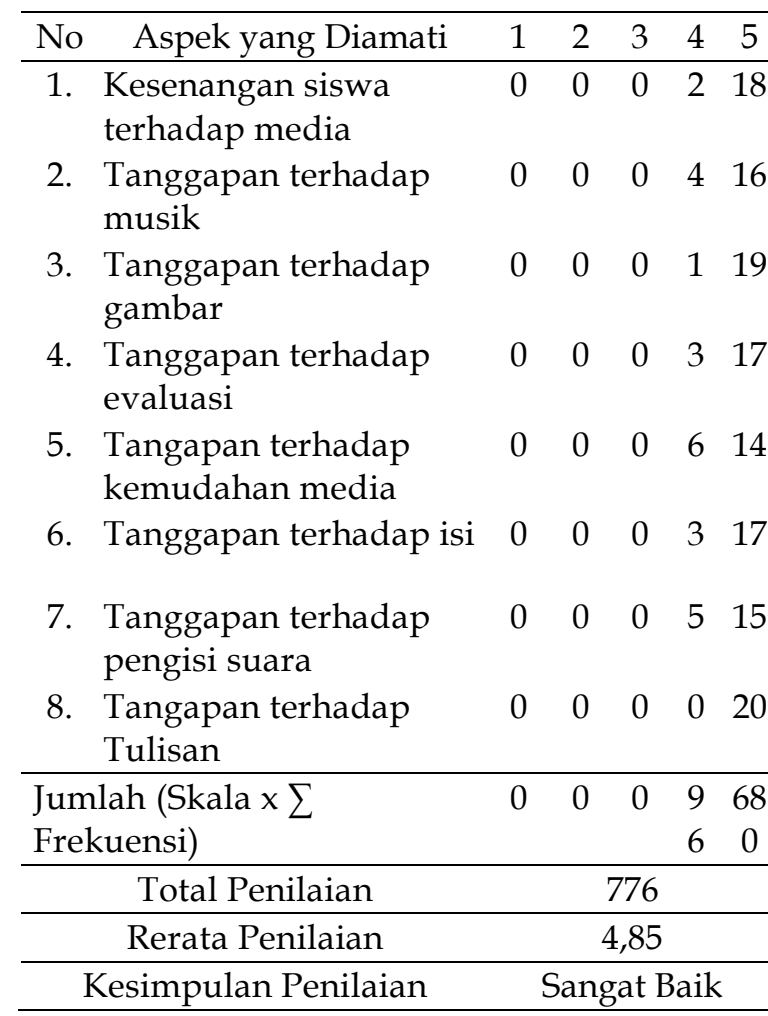

Tabel 10. Data Nilai Pretes-postes kuis 1 Media pembelajaran membaca berbantuan komputer untuk peserta didik kelas I Sekolah Dasar

\begin{tabular}{clccc}
\hline No & Nama & Pretes & Postes & Persentase \\
\hline 1 & Sunu & 5 & 8 & $60 \%$ \\
2 & Eriand & 6 & 9 & $50 \%$ \\
3 & Nasywa & 4 & 8 & $100 \%$ \\
4 & Nuha & 5 & 8 & $60 \%$ \\
5 & Indi & 6 & 9 & $50 \%$ \\
6 & Dhani & 7 & 9 & $28 \%$ \\
7 & Aura & 6 & 10 & $67 \%$ \\
8 & Audi & 6 & 9 & $50 \%$ \\
9 & Hani & 5 & 8 & $60 \%$ \\
10 & Anindya & 4 & 8 & $100 \%$ \\
11 & Jovanta & 6 & 8 & $33 \%$ \\
12 & Welly & 5 & 9 & $80 \%$ \\
13 & Tania & 5 & 8 & $60 \%$ \\
14 & Raffi & 6 & 9 & $50 \%$ \\
15 & Allesia & 7 & 10 & $43 \%$ \\
16 & Rani & 5 & 9 & $80 \%$ \\
17 & Sita & 6 & 8 & $33 \%$ \\
18 & Tya & 5 & 8 & $60 \%$ \\
19 & Salwa & 6 & 9 & $50 \%$ \\
20 & Fiqi & 6 & 9 & $50 \%$ \\
\hline
\end{tabular}

Tabel 11. Data Nilai Pretes-postes kuis 2 Media pembelajaran membaca berbantuan komputer untuk peserta didik kelas I Sekolah Dasar

\begin{tabular}{cllll}
\hline No & Nama & Pretes & Postes & persentase \\
\hline 1 & Sunu & 6 & 9 & $50 \%$ \\
2 & Eriand & 5 & 8 & $60 \%$ \\
3 & Nasywa & 5 & 8 & $60 \%$ \\
4 & Nuha & 5 & 8 & $60 \%$ \\
5 & Indi & 6 & 9 & $50 \%$ \\
6 & Dhani & 7 & 10 & $43 \%$ \\
7 & Aura & 6 & 9 & $50 \%$ \\
8 & Audi & 5 & 9 & $80 \%$ \\
9 & Hani & 5 & 8 & $60 \%$ \\
10 & Anindya & 5 & 8 & $60 \%$ \\
11 & Jovanta & 6 & 9 & $50 \%$ \\
12 & Welly & 5 & 8 & $60 \%$ \\
13 & Tania & 6 & 8 & $33 \%$ \\
14 & Raffi & 6 & 9 & $50 \%$ \\
15 & Allesia & 7 & 10 & $43 \%$ \\
16 & Rani & 5 & 8 & $60 \%$ \\
17 & Sita & 5 & 8 & $60 \%$ \\
18 & Tya & 5 & 8 & $60 \%$ \\
19 & Salwa & 6 & 9 & $50 \%$ \\
20 & Fiqi & 6 & 9 & $50 \%$ \\
\hline
\end{tabular}

Dari data tersebut, dapat diketahui bahwa terjadi peningkatan hasil belajar siswa setelah belajar menggunakan media pembelajaran membaca berbantuan komputer yang dibuat.

\section{Simpulan}

Berdasarkan hasil penelitian dan pengembangan produk multimedia pembelajaran membaca untuk siswa kelas 1 sekolah dasar, disimpulkan sebagai berikut.

Pertama, produk akhir penelitian pengembangan ini adalah software media pembelajaran membaca berbantuan komputer untuk peserta didik kelas 1 sekolah dasar yang siap digunakan baik dalam proses belajar mengajar di kelas ataupun digunakan secara mandiri dengan karakteristik sebagai berikut.

Media ini berbentuk tutorial dengan menampilkan perpaduan antara kata, gambar sebagai konsep dari kata tersebut, dan pengucapannya. 
Kedua, penilaian ahli materi mengenai kualitas media PBK yang dikembangkan ini adalah sangat baik, dengan rerata skor sebesar 4,6, ahli media menilai sangat baik, dengan rerata skor sebesar 4,47 , guru menilai sangat baik, dengan skor rerata 4,84 dan peserta didik pada uji coba lapangan memberikan tanggapan media PBK adalah sangat baik dengan rerata skor sebesar 4,85, pada skala 1-5. Dari hasil pengukuran terhadap efektivitas media dalam meningkatkan hasil belajar, diperoleh data dan kesimpulan bahwa media pembelajaran membaca berbantuan komputer untuk peserta didik kelas 1 Sekolah Dasar ini dapat meningkatkan kemampuan belajar membaca siswa.

Saran

Berdasarkan kesimpulan dan keterbatasan di atas, dapat disarankan sebagai berikut.

Pertama, produk media PBK ini layak dimanfaatkan dalam proses pembelajaran membaca untuk siswa kelas 1 sekolah dasar agar proses pembelajaran lebih menarik, efisien, dan memotivasi kemandirian belajar peserta didik. Produk ini dapat juga dimanfaatkan sebagai variasi metode pembelajaran membaca tingkat awal.

Kedua, produk media PBK ini disosialisasikan lebih luas, sehingga penggunaaan multimedia ini dapat menjad alternatif pembelajaran membaca awal baik secara mandiri maupun dalam proses pembelajaran di kelas.

Ketiga, mengingat masih adanya kekurangan dan kelemahan pada media PBK ini, maka perlu dilakukan penyempurnaan, terutama untuk variasi materi dan kemampuan untuk menguji secara auditif keterampilan membaca nyaring pengguna.

\section{Daftar Pustaka}

Criswell, E.L. (1989). The design of computer based instruction. New York: Macmillan Publishing Company

Departemen Pendidikan Nasional. (2003). Kurikulum 2004 standar kompetensi mata pelajaran bahasa indonesia sekolah dasar dan madrasah ibtidaiyah. Jakarta: Pusat Kurikulum.

Dick, W. \& Carey. (1985) The systematic design of instruction (2nd edition). Gleeview, Illonions. Harper Collins College Publishers.

Hannafin, Michael J. (1988). The design, development, and evaluation of instructional software. New York: Macmillan Publishing Company.

Heinich, R (et al). (2005). Instructional media and technologies for learning (8 $8^{\text {th }}$ edition), Upper saddle River, New Jersey: Pearson Merril Prentice Hall.

Tarigan, H.G. (1985). Membaca sebagai suatu keterampilan berbahasa. Bandung: Angkasa.

Munir. (2012). Multimedia, konsep dan aplikasi dalam pendidikan. Bandung: Alfabeta

Nana Sudjana. (1991). Teori-teori Belajar untuk Pengajaran. Jakarta: Lembaga Penerbit Fakultas Ekonomi UI.

Nana Sudjana dan Ahmad Rivai. (1989). Teknologi pengajaran. Bandung: Sinar Baru.

Nana Syaodih Sukmadinata. (2007). Metode penelitian pendidikan. Bandung: Rosda.

Philip. R. (1997). The developer's handbook to interactive multimedia. London: Kogan Page

Punaji Setyosari. (2012). Metode penelitian pendidikan dan pengembangan. Jakarta: Kencana.

Pusat Kurikulum Departemen Pendidikan Nasional. (2007). Naskah akademik kajian kebijakan kurikulum mata pelajaran bahasa. Jakarta: Departemen Pendidikan Nasional

Sugiyono. (2006). Metode penelitian pendidikan. Bandung: Alfabeta

Wasis D. Dwiyogo. (19-20 Juli 2004). Konsep penelitian $\mathcal{E}$ pengembangan. Makalah disajikan pada Lokakarya Nasional Metodologi Penelitian Pengembangan Bidang Pendidikan dan Pembelajaran di Universitas Negeri Yogyakarta. 